\title{
Effect of Water Absorption on Color Stability of Different Resin Based Restorative Materials in Vitro Study
}

\author{
Fatma Mohamed EL-Sharkawy ${ }^{1, *}$, Nadia Mohamed Zaghloul ${ }^{2}$, Ahmed Mohsen Ell-kappaney ${ }^{3}$ \\ ${ }^{1}$ Photometry Department; National Institute of Standards, Giza, Egypt \\ ${ }^{2}$ operative and Conservative Dentistry department, Faculty of Dentistry, Mansoura University, Egypt \\ ${ }^{3}$ Conservative Dentistry Department, Faculty of Dentistry, Mansoura University, Egypt
}

\begin{abstract}
This study was designed to evaluate the effect of water absorption of three resin based composite materials on their color stability Methods: using scanning spectrophotometer. A total of 45 disc samples were constructed from microhybrid resin composite, polyacid modified resin composite and giomer. It should be mentioned that the selected shade is A2. Then inserted in water for water absorption test. Using five different drink [mouth rinse $\left(37^{\circ} \mathrm{C}\right)($ Chlorohexidine containing mouthwash), tea, coffee, red wine and de-ionized water $\left.\left(37^{\circ} \mathrm{C}\right)\right]$ with no exposure to a light source (neutral sample). Three specimens from each restorative material were made for each type of drink. All the color testing were carried out according to the CIE- $L^{*} a^{*} b^{*}$-color system whereby $L^{*}$ indicates the brightness of a color, $a^{*}$ describes the red-green content and $b^{*}$ the yellow-blue content.
\end{abstract}

Keywords Tetric Ceram, Giomer, Color Stability

\section{Introduction}

Exposure of different restorative materials for a long period of time to oral environment usually result in an interaction with oral fluids, the main effect of fluids is fluid absorption. Such fluid absorption may affect the mechanical properties of the material and cause damaging dimensional stability of the restoration and the associated tooth structure $^{[1,2]}$.

"Giomer" is one of the latest developments in fluoridereleasing materials. Giomer restoratives are marketed as being true hybrids of glass ionomer and resin composite and having the properties of fluoride release and fluoride recharge of glass ionomer cements plus the excellent esthetic properties ease of polishing, and strength characteristic of resin composites. The high levels of fluoride release and recharge of the giomers are attributed to the presence of a pre-reacted hydrogel ${ }^{[2]}$.

The staining of resin-based materials by colored solutions such as coffee, tea, and other beverages ${ }^{[3-11]}$, and color stability after aging in different solutions ${ }^{[12-13]}$ have been reported.

\section{Objectives}

Study the effect of water absorption on color stability of

* Corresponding author:

fsharkawy_2000@yahoo.com (Fatma Mohamed EL-Sharkawy)

Published online at http://journal.sapub.org/cmaterials

Copyright (C) 2012 Scientific \& Academic Publishing. All Rights Reserved the new branches of glass-ionomer i.e. Poly acid modified resin composite and giomer in comparison with resin composite materials.

\section{Methods}

A total of 45 disc samples of diameter and thickness equal to 3 and $2 \mathrm{~mm}$ respectively were constructed from microhybrid resin composite, polyacid modified resin composite and giomer, each of them contain 15 disc samples. Another 45 disc samples as mentioned before, number coded, then stored in de-ionized water for the initial 24 hour then the samples were tested for color measurements (zero value) using Shimadzu 3101PC spectrophotometer. The surface were scanned at wavelengths from $380 \mathrm{~nm}$ to $780 \mathrm{~nm}$ with the monochromator slit width at $5 \mathrm{~nm}$ and operated at a scan rate of $100 \mathrm{~nm} / \mathrm{min}$ to obtain maximum accuracy. The materials used are summarized in table 1.

\subsection{Water Absorption Test}

A disc mold is fabricated from a Teflon material, with a thickness of $2 \mathrm{~mm}$, and internal hole of $3 \mathrm{~mm}$ diameter, into two halves. The two halves were inserted into a stainless steel key to ensure re-assembly. A total of 45 disc samples of diameter and thickness equal to 3 and $2 \mathrm{~mm}$ respectively were constructed from microhybrid resin composite, polyacid modified resin composite and giomer, each of them contain 15 disc samples. It should be mentioned that the selected shade is A2 to standardize the degree of polymerization. 
Table 1. Show Restorative Systems and Classification of the materials used

\begin{tabular}{|c|c|c|c|}
\hline Restorative Systems & Classification & composition & company \\
\hline $\begin{array}{l}\text { Tetric Ceram resin } \\
\text { composite and Its } \\
\text { specific } \\
\text { Adhesive } \\
\text { System(excite) }\end{array}$ & $\begin{array}{l}\text { Micro hybrid resin } \\
\text { Composite restoration and total } \\
\text { etch bonding system (exite bond) } \\
\text { with its specific Etching gel } \\
\text { ( } 37 \% \text { Phosphoric acid) }\end{array}$ & $\begin{array}{l}\text { Resin: Bis-GMA-Urethane dimethacrylate and decandiol Dime- } \\
\text { thacrylate } \\
\text { Filler(81\%by weight): Barium glass, Ytterbium trifluoride and } \\
\text { Ba-Alfluorosilicate glass } \\
\text { Exite bond: Mixture of dimethacrylates, alcohol, phosphonic } \\
\text { acid acrylate, } \\
\text { HEMA (hydroxyethyl methacrylate), SiO2, initiators and stabi- } \\
\text { lizers }\end{array}$ & $\begin{array}{l}\text { Ivoclar } \\
\text {-Vivadent }\end{array}$ \\
\hline $\begin{array}{l}\text { Dyract extra and Its } \\
\text { specific } \\
\text { Adhesive } \\
\text { system }\end{array}$ & $\begin{array}{l}\text { Poly acid modified resin com- } \\
\text { posite and total etch bonding } \\
\text { system(Prime\&Bond® NTTM) } \\
\text { with its specific Etching gel } \\
\text { ( } 37 \% \text { Phosphoric acid) }\end{array}$ & $\begin{array}{l}\text { Resin: urethane dimethacrylate (UDMA)-Carboxylic acid mod- } \\
\text { ified dimethacrylate (TCB resin) } \\
\text {-Triethyleneglycol dimethacrylate (TEGDMA) } \\
\text {-Trimethacrylate resin } \\
\text {-Camphorquinone } \\
\text { Filler: Strontium-alumino-sodium-fluoro-phosphor-silicate } \\
\text { glass, silicon dioxide and Strontium fluoride } \\
\text { Prime\&Bond }{ }^{\circledR} \text { NTTM: } \\
\text { Di- and Trimethacrylate resins } \\
\text { PENTA (dipentaerythritol penta acrylate monophosphate) } \\
\text { Nanofillers-Amorphous Silicon Dioxide } \\
\text { Photoinitiators,Stabilizers }\end{array}$ & DENTSPLY $^{\mathrm{ii}}$ \\
\hline $\begin{array}{l}\text { Beautiful and } \\
\text { Its specific } \\
\text { Adhesive } \\
\text { system }\end{array}$ & $\begin{array}{l}\text {-Giomer. } \\
\text {-Three step etch and rinse bond- } \\
\text { ing system } \\
\text { SHOFU-FL-BOND with its spe- } \\
\text { cific Etching gel ( } 37 \% \text { Phos- } \\
\text { phoric acid) }\end{array}$ & $\begin{array}{l}\text { Resin: Urethane dimethacrylate (UDMA) - Hydroxyethylmetha- } \\
\text { crylate( HEMA). } \\
\text { Filler(83.3wt\%): S-PRG (surface pre-reacted glass iono- } \\
\text { mer)marketed as beautiful shofu } \\
\text { SHOFU-FL-BOND: } \\
\text { Contains a new effective adhesion promoting monomer and is } \\
\text { acetone free with no incorporation of HEMA to minimize odor } \\
\text { and post operative sensitivity. } \\
\text { The FL-BOND II BONDING AGENT: Contains the S-PRG }\end{array}$ & Shofuii \\
\hline
\end{tabular}

The mold was assembled over a glass slide with thickness (3 $\mathrm{mm})$, covered with a $0.05 \mathrm{~mm}$ transparent polyethylene film. The mold space was filled with the test material in a bulk pack technique, avoiding gross excess and entrapping of air. Another $0.05 \mathrm{~mm}$ transparent polyethylene film was applied to the top of the mold and covered with another glass slide. The applied material was light cured for 40 seconds from each side using light emitting diode (LED) curing unit with an intensity of $\left(500 \mathrm{~mW} / \mathrm{cm}^{2}\right)$. The specimens were prepared at room temperature. It should be mentioned that the light intensity was re-measured each five samples using, cure rite (visible curing light meter), to assure standardized hardening for all composite restorations during photo curing.

After fabrication, each sample was number coded and the weight for each of them is measured by digital scale*** before immersion in water (base time). Then water absorption test is carried out by immersing disc samples in water bath (distilled water) at $55^{\circ} \mathrm{C}$. The weight gains of the samples were measured again after 24 hours \& 7 days.

\subsection{Color Stability Test}

All disc samples were prepared as mentioned before, number coded, then stored in de-ionized water for the initial 24 hour at $37 \circ \mathrm{C}$ to assure complete polymerization of all samples. At the end of this time, the samples were tested for color measurements (zero value) using ShimazuUV-
3101PC (UV-VIS-NIR scanning spectrophotometer). Three specimens from each restorative material were made for each type of drink as follow:

Subgroup B1: Storage in a mouth rinse $\left(37^{\circ} \mathrm{C}\right)$ (Chlorohexidine containing mouthwash)

Subgroup B2: Storage in tea

Subgroup B3: Storage in coffee

Subgroup B4: Storage in red wine

Subgroup B5: Storage in de-ionized water $(37 \circ \mathrm{C})$ with no exposure to a light source (neutral sample).

The drinks were changed after every 48 hour of immersion. Color testing was carried out after 4 and after 8 weeks. All the color testing were carried out according to the CIE$L^{*} a^{*} b^{*}$-color system with a spectrophotometer CIE- $L^{*} a^{*} b^{*}-$ color system uses the three dimensionless colorimetric measurements $L^{*}, a^{*}$ and $b^{*}$ whereby $L^{*}$ indicates the brightness of a color, $a^{*}$ describes the red-green content and $b^{*}$ the yellow-blue content.

Prior to taking measurements, deposits on the surface of the samples were removed by ultrasonic cleaning for $5 \mathrm{~min}$ and the surfaces were dried with disposable paper tissue. For each sample, three repeated measurements were taken to determine the colorimetric values i.e. $L^{*}$ (brightness), $a^{*}$ (red-green proportion) and $b^{*}$ (yellow-blue proportion). The differences to the zero value were calculated from the means of the colorimetric values $\Delta L^{*}, \Delta a^{*}$ and $\Delta b^{*}$. Then, the total 
color difference $\Delta E$ for each sample was calculated using the following equation ${ }^{[14]}$

$$
\Delta E=\sqrt{\left(\Delta L^{*}\right)^{2}+\left(\Delta a^{*}\right)^{2}+\left(\Delta b^{*}\right)^{2}}
$$

\section{Results}

The lowest water absorption mean was found in microhybrid resin composite while both polyacid modified resin composite and giomer have higher water absorption values.

Table (2-a)

\begin{tabular}{|c|c|c|c|}
\hline Type of composite & $\mathrm{N}$ & Mean $(\mu \mathrm{m} / \mathrm{m})$ & S.D \\
\hline Microhybrid resin composite & 15 & $0.22792000 \mathrm{a}$ & 0.00270078 \\
\hline $\begin{array}{c}\text { Polyacid modified resin } \\
\text { composite }\end{array}$ & 15 & $0.26902667 \mathrm{~b}$ & 0.03612873 \\
\hline Giomer & 15 & $0.26976000 \mathrm{~b}$ & 0.01851246 \\
\hline P value & \multicolumn{3}{|c|}{$<.0001$} \\
\hline LSD & \multicolumn{3}{|c|}{0.0235} \\
\hline
\end{tabular}

The lowest color changes were found in microhybrid resin composite (tetric ceram) 7.31470372 to be followed by giomer 8.48082264, While polyacid modified resin composite shows the highest degree of color change.

Table (2-b)

\begin{tabular}{|c|c|c|c|}
\hline Type of composite & $\mathrm{N}$ & Mean & S.D \\
\hline Tetric ceram & 30 & $7.31470372 \mathrm{a}$ & 1.83957976 \\
\hline giomer & 30 & $8.48082264 \mathrm{~b}$ & 1.99978436 \\
\hline $\begin{array}{c}\text { poly-acid modified resin } \\
\text { composite }\end{array}$ & 30 & $8.64408931 \mathrm{~b}$ & 2.35192191 \\
\hline P value & \multicolumn{3}{|c|}{$<.0001$} \\
\hline LSD & \multicolumn{3}{|c|}{0.3447} \\
\hline
\end{tabular}

Table (2-a)\& Table (2-b) Show the statically analyses for water absorption.

\section{Discussion}

Water absorption values of micro hybrid resin composites are significantly less than poly-acid modified resin composites and giomer restorations. The nature of the resin matrix is a fundamental parameter in water absorption property of the resin based materials, which may control not only the rate of diffusion of water but also the extent of water sorption into that part of the material structure. Hydrophilic monomers such as Hydroxyethylmethacrylate (HEMA) used in manufacturing of giomer and acid containing methacrylates used in manufacturing of poly-acid modified resin composites are all expected to increase water absorption above what would be expected from a more hydrophobic dimethacrylate used for micro-hybrid resin composite. Although the presence of hydrophilic monomers may influence the rate and degree of water absorption it is not the only factor; nor necessarily the dominant factor.

Microhybrid resin composites have the lowest degree of water absorption as it may be due to only hydrophobic monomers are present in its resin matrix on the other hand giomer and poly-acid modified resin composite has higher degree of water absorption.

Another explanation to the increased water absorption in poly-acid modified resin composite in comparison with micro hybrid resin composite is the presence of Hydrophilic monomers such as hydroxyethylmethacrylate besides acid containing methacrylates which increase water absorption in poly-acid modified resin composite

Regarding to the highest degree of water absorption recorded with giomer restorative materials it may be due to presence of pre-reacted glasspolyacid zones which become part of the filler in the giomer structure. It seems likely that these zones are responsible for generating the osmotic effect which leads to water absorption, swelling and pressure. Similar zones can potentially be formed at the surface of compomer glass particles following the delayed acid-base reaction which occurs following water absorption. Clearly, the mechanism and degree of absorption differs amongst the various test materials. The giomer product appeared to be able to generate osmotic pressure during water storage and this may be due to the pre-reacted zones on the surface of glass filler particles.

While in color stability test, the red wine and the mouthwash proved to be especially effective and caused severe discoloration in all the tested composites. To be followed by coffee then tea then water which shows least color change. Red wine may cause the highest degree of color change as it contains $16 \%$ alcohol which increase dissolution of resin matrix and increase absorption of fluids.

Two comments can be made concerning the experimental set-ups. Firstly, the samples were, for reasons of reproducibility, only smoothed with abrasive paper grain 240,400 , 600 and 1200 and not subjected to dental polishing. Owing to the relatively rough surface, we may assume an increased super-facial color adsorption. According to Ludwig, however, primarily smooth facings in vivo display micro-surface roughness after a while. Secondly, it is unclear to what extent these results have any clinical relevance since we cannot assume such long-term contact of a restoration and a substance containing a coloring agent in the oral cavity. Nevertheless, in daily clinical practice, we know that there are a great many complaints about discoloration of resin-based composite restorations. Since in our investigation, discoloration due to tea, coffee, red wine, we may assume that coloring agents contained in nutrition contribute to the clinically observed discoloration of resin-based composite restorations ${ }^{[15]}$.

\section{Conclusions}

Under the conditions of the present investigation it can be concluded that:-

1- Although there was increasing developments in the glass ionomer technologies, water absorption and color stability are still a great problem associated with all modified glass ionomer restorative materials. 
2-In addition to the documented different health hazards of the red wine intake, it is approved that even it has a deteriorating effect on the restorative materials.

3-It is obvious that there is a direct relation between the degree of water sorption of different restorative materials and either color stability and marginal integrity.

\section{Recommendations}

1-For esthetic purposes, it is better to use resin based composite restorations, despite of glass ionomer versions of composite modified restoration

2-Further investigation may be required to study whether discoloration of the materials is related to either surface or body discoloration.

3-Modifications in the technology of glass ionomer restorations are required to improve their water absorption property to improve the overall physical and mechanical properties of the materials.

\section{REFERENCES}

[1] Parker S, Braden M.: Water absorption of methacrylate soft lining materials. Biomater 1989; 10:91-5.

[2] Sunico MC, Shinkai K, Katoh Y: Two-year clinical performance of occlusal and cervical giomer restorations.Oper Dent 30:282-289, 2005.

[3] Iazzetti G, Burgess JO, Gardiner D, Ripps A: Color stability of fluoride containing restorative materials. Oper Dent 2000; 25:520-5.

[4] Abu-Bakr N, Han L, Okamato A, Iwaku M: Color stability of compomer after immersion in various media. J Esthet Dent $2000 ; 12: 258-63$.
[5] Satou N, Khan AM, Matsumae I, Satou J, Shintani H: In vitro color change of composite-based resins. Dent Mater 1989; 5:384-7.

[6] 13. Gross MD, Moser JB. A colorimetric study of coffee and tea staining of four composite resins. J Oral Rehabil 1977;4:311-22.

[7] Wozniak WT, Muller TP, Silverman R, Moser JB: Photographic assessment of colour changes in cold and heat-cure resins. J Oral Rehabil 1981; 8: 333-9.

[8] Ruyter IE, Nilner K, Moller B: Color stability of dental composite resin materials for crown and bridge veneers. Dent Mater 1987; 3:246-51.

[9] Burrow MF, Makinson OF: Color change in light-cured resins exposed to daylight. Quintessence Int 1991; 22:447-52.

[10] Lu H, Roeder LB, Lei L, Powers JM: Effect of surface roughness on stain resistance of dental resin composites. J Esthet Restor Dent 2005; 17:102-8.

[11] Lee YK, Lu H, Powers JM : Effect of surface sealant and staining on the fluorescence of resin composites. J Prosthet Dent 2005; 93:260-6.

[12] Wilson NH, Burke FJ, Mjor IA: Reasons for placement and replacement of restorations of direct restorative materials by a selected group of practitioners in the United Kingdom. Quint. Int 1997; 28:245-8.

[13] Fulya TT, Gunes S, Kivanc Y, Ugur E, Elif AO, and Seyda E: Influence of Different Drinks on the Colour Stability of Dental Resin Composites. Eur J Dent. 2009 January; 3(1): $50-56$.

[14] CIE (Commission International de l'Eclairage) Colourimetry technical report. CIE Publication No.15. 2. Vienna, Austria: Bureau Central de la CIE; 1986.

[15] Awliya WY, Al-Alwani DJ, Gashmer ES and Al-Mandil, HB. The effect of commonly used types of coffee on surface microhardness and color stability of resin-based composite restorations. Saudi Dent J, 2011; 22: 177-181. 